\title{
Natural Chlorins Octadecylamides - Upconversion Nanoparticles Complexes for the Study of Energy Transfer Process
}

\author{
Andrei V. Nechaev, ${ }^{\mathrm{a}, \mathrm{b} @ ~ M a r y a ~ E . ~ N i k o l a e v a, ~}{ }^{\mathrm{a}, \mathrm{b}}$ Ilya M. Asharchuk, $^{\mathrm{b}}$

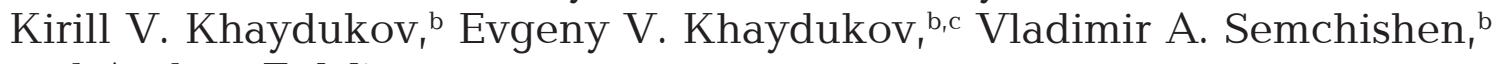 \\ and Andrey F. Mironov ${ }^{\mathrm{a}}$ \\ anstitute of Fine Chemical Technologies, Moscow Technological University, 119571 Moscow, Russia \\ 'Federal Scientific Research Centre "Crystallography and Photonics” of Russian Academy of Sciences, 119333 Moscow, \\ Russia \\ ${ }^{\mathrm{c}}$ Center of Bioimaging, Institute for Regenerative Medicine, Sechenov First Moscow State Medical University, 119991 \\ Moscow, Russia \\ ${ }^{\circledR}$ Corresponding authorE-mail: chemorg@mail.ru
}

\begin{abstract}
A series of natural chlorins with octadecylamine residue in pyrrole rings $A$ and $D$ have been prepared on the basis of chlorophyll a derivatives. The compounds are capable to form intermolecular conjugates with upconversion nanoparticles (UCNP) due to hydrophobic interactions with oleic acid on the surface of nanocrystals. Coincidence of the intensive chlorin absorption band with UCNP fluorescence in red range of spectrum results in Förster resonance energy transfer (FRET).
\end{abstract}

Keywords: Upconversion nanoparticles, natural chlorins, chlorin $p_{6}$, pyropheophorbide, octadecylamides, FRET.

\section{Комплексы октадециламидов природных хлоринов с апконвертирующими наночастицами Аля изучения процесса переноса энергии}
A. B. Нечаев, ${ }^{a, b @}$
М. Е. Николаева, ${ }^{a, b}$
И. М. Ашарчук, ${ }^{\mathrm{b}} \mathrm{K}$
В. Хайдуков, ${ }^{\text {b }}$
Е. В. Хайдуков,
В. А. Семчишен, ${ }^{b}$ А. Ф. Миронов ${ }^{a}$

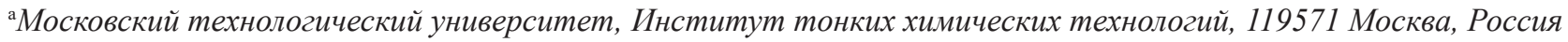

'Федеральный научно-исследовательский цеентр “Кристаллография и Фотоника” Российской академии наук, 119333

Москва, Россия

' ФГБОУ ВО Первый МГМУ им. И.М. Сеченова Минздрава России, Институт регенеративной медицины,

лаборатория экспериментального оптического имиджинг, 119991 Москва, Россия

@E-mail: chemorg@mail.ru

\begin{abstract}
На основе производных хлорофилла а получена серия природных хлоринов с гидрофобным остатком октадециламина в пиррольных кольцах $A$ и D макрочикла. Полученные соединения способны образовывать межмолекулярные конъюгаты с апконвертирующими наночастицами за счет гидрофобных взаимодействий с остатками олеиновой кислоть на поверхности нанокристаллов. Практически полное совпадение интенсивной полосы поглощчения хлоринов и красной области флуоресценщии апконвертирующей частищы позволяют наблюдать явление Ферстеровского резонансного безызлучательного переноса энергии (ФРЭТ).
\end{abstract}

Ключевые слова: Апконвертирующие наночастицы, природные хлорины, хлорин $p_{6}$, пирофеофорбид, октадециламиды, ФРЭТ. 
Upconversion nanoparticles (UCNPs) possess the unique photophysical and spectral characteristics ${ }^{[1-3]}$ that have found potential applications in theranostics for visualization and therapy of malignant tumors. UCNP represent a nontoxic inorganic crystal matrix of the composition $\mathrm{NaYF}_{4}$ co-doped with various lanthanides (Yb, Er, Tm). The UCNP spectral properties can be easily tuned via adjusting the percentage of lanthanide ions in composition. ${ }^{[4-6]}$ One approach for application of UCNPs in theranostics is producing of intermolecular complexes of such phosphors with various photosensitizers (PS) for use in photodynamic therapy (PDT) of cancer. ${ }^{[7,8]}$ Excitation wavelength $(980 \mathrm{~nm})$ and the main photoluminescence peaks of UCNP are in infrared, red and green ranges of spectrum. Therefore, investigation of these complexes is considerably simplified due to the absence of the luminescence of biological tissues. Both natural and synthetic photosensitizes ${ }^{[9-13]}$ are applied as components of a complex.

In this paper we describe the synthesis of noncovalent complexes of natural chlorins with UCNPs for energy transfer investigations from the particle to PS. Due to synthetic procedure features, the particles have oleic acid residue with hydrophobic nature on the surface. Nanoparticle structure $\beta-\mathrm{NaY}_{0.78} \mathrm{~F}_{4}, \mathrm{Y}_{0.2} \mathrm{Er}_{0.2}$ is most widely used. The photoluminescence spectrum of nanoparticles has two main peaks at 540 and $650 \mathrm{~nm}$ when excited by $975 \mathrm{~nm}$ laser radiation. [14] In the current work we used nanocrystals $\beta-\mathrm{NaY}_{0.798} \mathrm{~F}_{4}$, $\mathrm{Y}_{0.2} \mathrm{Er}_{0.02}$ with 10 times smaller erbium content. Such change of structure causes the prevalence of red peak in the spectrum, and almost completely coincides with the intensive chlorin absorption band.

$28 \mathrm{~nm} \quad \beta-\mathrm{NaY}_{0.798} \mathrm{~F}_{4}, \mathrm{Y}_{0.2} \mathrm{Er}_{0 .} 02 @ \mathrm{NaYF}_{4} \quad$ core/shell UCNP was synthesized as described in our recent work. ${ }^{[15]}$ The produced nanocrystals indicate $3 \%$ upconversion efficiency at the excitation intensity $10 \mathrm{~W} / \mathrm{cm}^{2}$ (Figure 1). The inactive shell is used to decrease the surface effects of fluorescence quenching and allows increasing UCNP brightness by 6 times. The synthesized nanocrystals are well dispersed in nonpolar organic solvents, such as hexane, chloroform, etc.

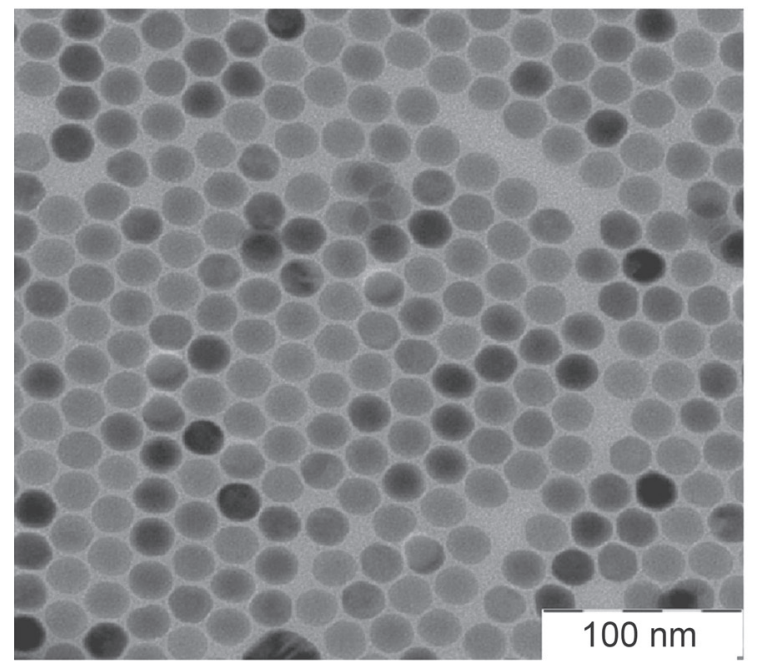

Easily available pyropheoforbide $a(\mathbf{1})^{[16]}$ and chlorin $p_{6}$ dimethyl ester (2) ${ }^{[17]}$ were used as starting chlorins for conjugates synthesis. At first the vinyl group in $\mathbf{1}$ was converted to aldehyde $3^{[18]}$ and then it was oxidized to carboxylic acid by sodium chlorite treatment. ${ }^{[19]}$ The obtained acid (4) was activated by disuccinimidyl carbonate (DSC) and conjugated with octadecylamine to form the octadecylamide (5) in $56 \%$ yield (Figure 2). Presence of carboxyl group in $17^{3}$-position allows further modification of the molecule.

Similarly, chlorin $p_{6}$ dimethyl ester (2) was converted to octadecylamide derivative $\mathbf{6}$ in $88 \%$ yield. Octadecylamine had a similar length as the oleic acid residue on the nanoparticle surface, that provided the good hydrophobic interaction between conjugate components.

Then obtained chlorins were conjugated with UCNPs, using hydrophobic interactions between octadecylamine and oleic acid residues. Results of photophysical researches were similar in both cases, therefore herein the description for compound $\mathbf{6}$ is represented. Nanoparticles were dispersed in chloroform in concentration $1 \mathrm{mg} / \mathrm{ml}$. Then excess of chlorin in chloroform was added and mixture was sonicated for $3 \mathrm{~min}$. Further suspension was diluted with an isopropanol and centrifuged at $6000 \mathrm{rpm}$ for 30 minutes. Resulting black-green precipitate was separated from excess of chlorin and centrifuged in isopropanol/chloroform mix three times, and then dispersed in chloroform and subjected to the energy transfer study (Figure 3).

Fluorolog-3 HJY fluorimeter (HJY, France) equipped with photomultiplier tube (PMT, Hamamatsu R929P) was used to measure photoluminescence (PL) spectrum and kinetics of the nanoparticles and conjugates. The PMT signal was registered by means of the high-speed oscilloscope (Tektronix TDS 6804B, USA). The quartz cuvette with sample was placed in a fluorimeter cuvette compartment. The semiconductor ATC laser (Semiconductor devices, Russia) was utilized as an excitation source. Exciting radiation at $975 \mathrm{~nm}$ from optical fiber was focused in the cuvette compartment using the quartz lens. Power density was a constant at all measurements and was equal to $50 \mathrm{~W} / \mathrm{cm}^{2}$. The duration of laser pulses was $2 \mathrm{~ms}$ at repetition rate of $70 \mathrm{~Hz}$.

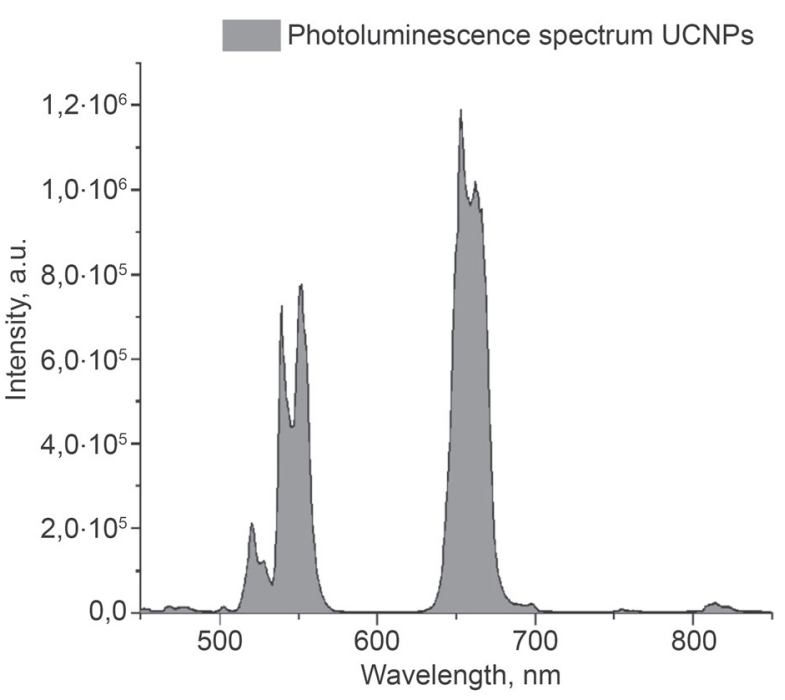

Figure 1. TEM image and photoluminescence spectrum of UCNPs. 

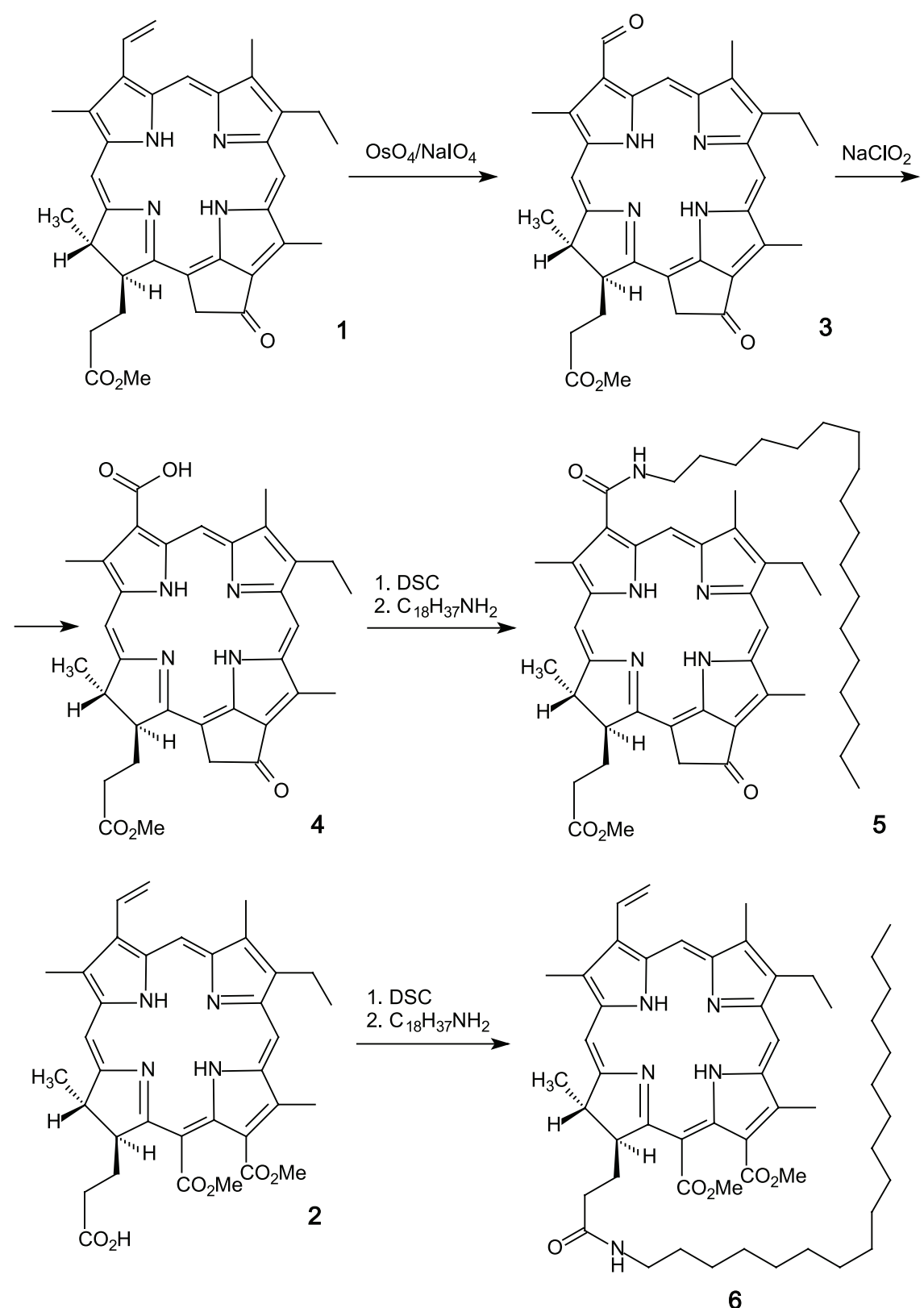

Figure 2. The synthesis of chlorins.

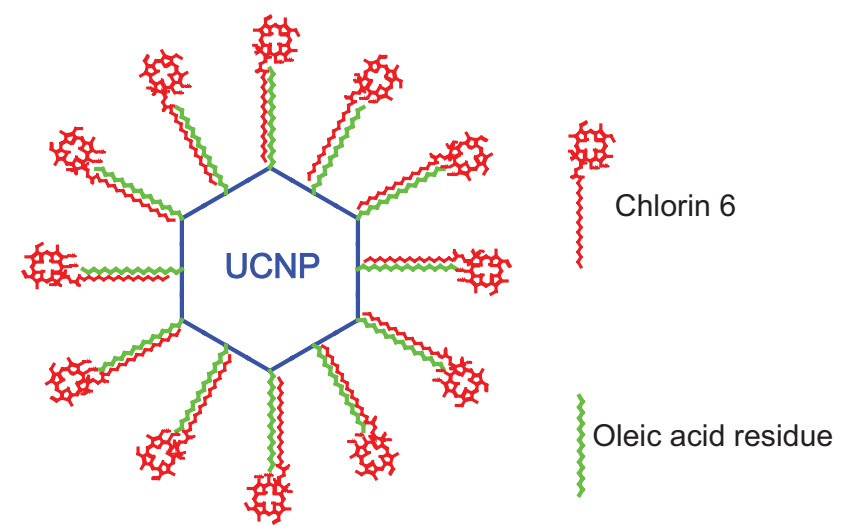

Figure 3. Schematic illustration of UCNP/Chlorin complex.
Figure 4 illustrates excitation of the chlorin and PL of the colloid of UCNP in chloroform. Nanoparticles possess the intensive PL lines around 540 and $650 \mathrm{~nm}$ when excited by laser radiation at $975 \mathrm{~nm}$. Chlorin has absorption bands at 540 and $660 \mathrm{~nm}$. It is visible that several bands of chlorin absorption coincide with certain bands of the upconversion luminescence of nanoparticles. Förster resonance energy transfer (FRET) between the acceptor and the donor occurs in this conjugate (Figure 4). Efficiency of energy transfer in the case of dipole-dipole interaction is inversely proportional to the sixth degree of distance between the donor and the acceptor.

Figure 5 demonstrates the spectrum of an anti-Stokes luminescence of conjugate $\mathrm{NaYF}_{4}: \mathrm{Yb}^{3+} \mathrm{Er}^{3+} @ \mathrm{NaYF}_{4} /$ chlorin in chloroform excited by the semiconductor laser at $975 \mathrm{~nm}$ wavelength and spectrum of the Stokes fluorescence of chlo- 


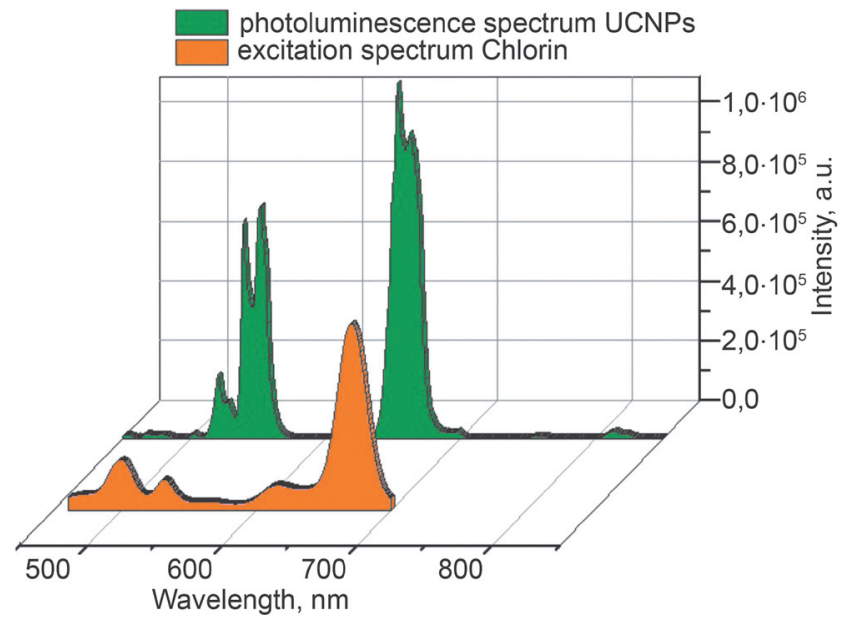

Figure 4. UCNP photoluminescence spectrum (green curve) at $975 \mathrm{~nm}$ excitation and power density $50 \mathrm{~W} / \mathrm{cm}^{2}$, and chlorin absorption spectrum (orange curve) in the range from 450 to $700 \mathrm{~nm}$.

rin. The spectrum of the molecular conjugate has the wide band of chlorin fluorescence with the maximum at $706 \mathrm{~nm}$ when excited by IR radiation. The bands of nanoparticle luminescence which are blocked with bands of excitement (absorption) of chlorin have low intensity in comparison to free UCNP at the similar conditions.

The measurement of luminescence lifetime of the donor at the presence and lack of the acceptor is required for estimation of resonance energy transfer efficiency, proceeding from the Förster formalism. Therefore, the following expression allows calculating the efficiency of the FRET process $(\eta)$ :

$$
\eta=1-\left(t_{D A} / t_{D}\right)
$$

where $t_{D A}$ is the lifetime of the donor at the presence of the acceptor, and $t_{D}$ is the lifetime of the donor at lack of the

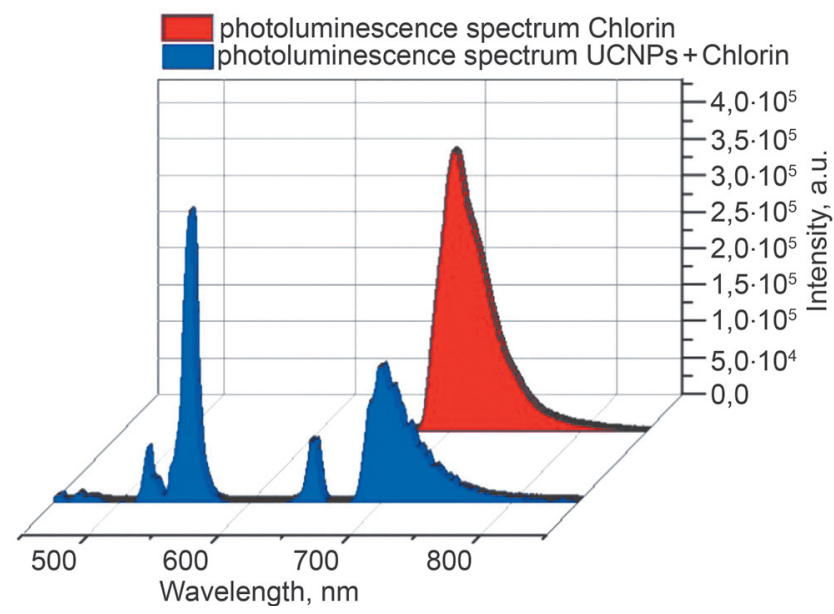

Figure 5. Stokes fluorescence spectra of chlorin at excitement by the light at $650 \mathrm{~nm}$ (red curve) and conjugate UCNP/Chlorin of anti-Stokes luminescence at excitement at $975 \mathrm{~nm}$ (blue curve). acceptor. The FRET efficiency can be also expressed as the percentage: $\eta \%=\eta \cdot 100 \%$.

For estimation of FRET efficiency we have measured the lifetimes of the excited state of $\mathrm{Er}^{3+}$ ions in nanoparticles. Results of measurements are presented in Figure 6. Lifetime of the excited state of $\mathrm{Er}^{3+}$ ions is $730 \mu \mathrm{s}$ in case of lack of the acceptor and $600 \mu$ s in case of a conjugate. Thus, energy transfer efficiency from the donor (UCNP) to the acceptor (chlorin) at $650 \mathrm{~nm}$ is $\sim 18 \%$.

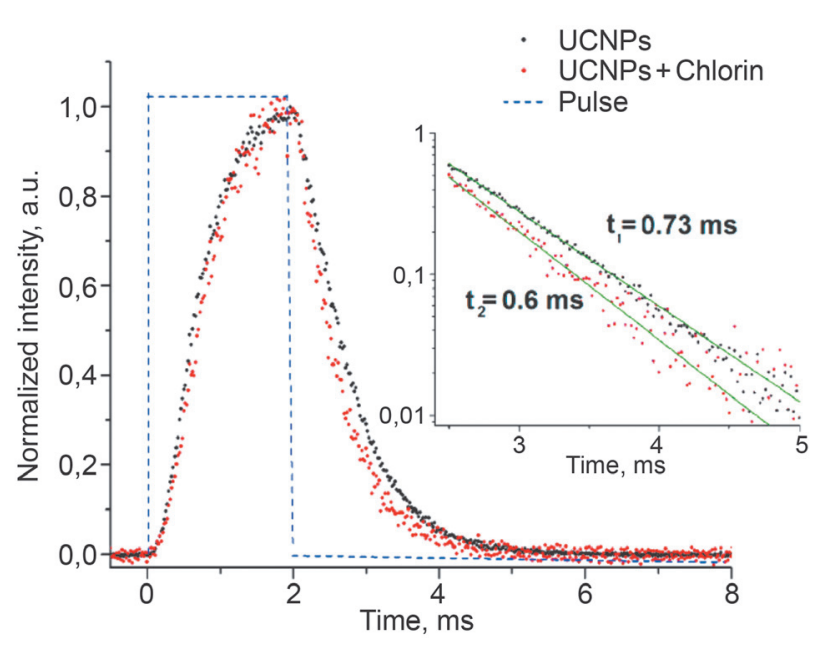

Figure 6. Time dependence of a luminescence at excitement by 2 ms pulse duration for nanoparticles (black curve) and a conjugate (red curve) at $650 \mathrm{~nm}$. The time profile of the exciting pulse at $975 \mathrm{~nm}$ is shown as the blue curve. The signals are normalized to unity. The starting of a timeline coincides with the beginning of excitement pulse. The quenching kinetics in half-logarithmic scale is presented in the inset.

Thus, it has been shown that chlorin derivatives with octadecylamine residue are capable to form intermolecular conjugates with UCNP due to hydrophobic interactions with oleic acid on the surface of nanocrystals. The FRET efficiency in such conjugates is around $18 \%$. Further therapeutic agents on the basis of such complexes can be applied for fluorescent visualization of tumors.

Acknowledgment. This work was supported by the RSF grant No.16-13-10092 in the part of chemical synthesis, and by the grant of RFBR No. 15-02-08697 in the part of photophysical experiments and FRET study.

\section{References}

1. Zhou J., Liu Q., Feng W., Sun Y., Li F. Chem. Rev. 2015, 115, 395-465.

2. Chen G., Qiu H., Prasad P.N., Chen X. Chem. Rev. 2014, 114, 5161-5214.

3. Gai S., Li C., Yang P., Lin J. Chem. Rev. 2014, 114, 2343-2389.

4. Chen G., Ohulchanskyy T.Y., Kumar R., Agren H., Prasad P.N. ACS Nano 2010, 4, 3163-3168.

5. Chen G., Ohulchanskyy T.Y., Kachynski A., Agren H., Prasad P.N. ACS Nano 2011, 5, 4981-4986.

6. Wang F., Liu X. Acc. Chem. Res. 2014, 47, 1378-1385. 
7. Wang C., Cheng L., Liu Z. Theranostics 2013, 3, 317-330.

8. Lucky S.S., Soo K.C., Zhang Y. Chem. Rev. 2015, 115, 1990-2042.

9. Guo H.C., Qian H.S., Idris N.M., Zhang Y. NanomedNanotechnol. 2010, 6, 486-495.

10. Shan J.N., Budijono S.J., Hu G.H., Yao N., Kang Y.B., Ju Y.G., Prud homme R. Adv. Funct. Mater. 2011, 21, 2488-2495.

11. Zhou A., Wei Y., Wu B., Chen Q., Xing D. Mol. Pharm. 2012, 9, 1580-1589.

12. Wang C., Tao H.Q., Cheng L., Liu Z. Biomaterials 2011, 32, 6145-6154.

13. Park Y.I., Kim H.M., Kim J.H., Moon K.C., Yoo B., Lee K.T., Lee N., Choi Y., Park W., Ling D., Na K., Moon W.K., Choi S.H., Park H.S., Yoon S.Y., Suh Y.D., Lee S.H., Hyeon T. Adv. Mater. 2012, 24, 5755-5761.
14. Wang F., Chatterjee D.K., Li Z., Zhang Y., Fan X., Wang M. Nanotechnology 2006, 17, 5786-5791.

15. Khaydukov E.V., Mironova K.E., Semchishen V.A., Generalova A.N., Nechaev A.V., Khochenkov D.A., Stepanova E.V., Lebedev O.I., Zvyagin A.V., Deyev S.M., Panchenko V.Y. Scientific Reports 2016, 6, 35103.

16. Brandis A.S., Kozyrev A.N., Mironov A.F. Tetrahedron 1992, 48, 6491-6499.

17. Mironov A.F., Nechaev A.V. Russ. J. Bioorg. Chem. 2001, 27, $120-123$.

18. Jhonson D.G., Svec W.A., Wasilewski M.R. Israel J. Chem. 1988, 28, 193-203.

19. Osuka A., Wada Y., Shinoda S. Tetrahedron 1996, 52, 43114326.

Received 22.11.2016

Accepted 09.12.2016 